\title{
The Effect of Adding Carbon (soot) to the Paint of an Absorbing Surface in Homemade Solar Systems
}

\author{
Hala K. Saleh \\ Department of Physics \\ College of Science \\ University of Mosul
}

(Received 14/ 12 / 2011 ; Accepted 14 / 2 / 2012 )

\begin{abstract}
Absorbing materials are key components of any solar water heater device. Silicon solar cells are very efficient but are highly expensive. An alternative is to use absorbing materials that are cheaper than silicon to produce. The use of carbon (soot) in the preparation of the coating layer of a homemade solar water heater has been investigated. When added in different proportions to oil-based white paint, marked increases in water temperatures were obtained. The increase in water temperature was directly proportional with the increase in the percentage of carbon in the coating layer. The maximum achieved outlet water temperature was $90^{\circ} \mathrm{C}$ in July and $70^{\circ} \mathrm{C}$ in November.

Due to its non-toxic nature and very low cost, carbon in the form of smoke suspension or soot, can provide a good and reliable alternative in the fabrication of domestic solar water heaters.
\end{abstract}

Keywords: carbon, coating, solar heater.

\section{تأثير إضلفة الكربهن عل اللالاء للملح المالفي المجمعات المنسية الحراربة}

\section{الملغص}

تعد المواد الماصة جزءا مهما لأي ظالمسخلن حراريشطسي. تكون خلايا للسليكا للشطسية ذات

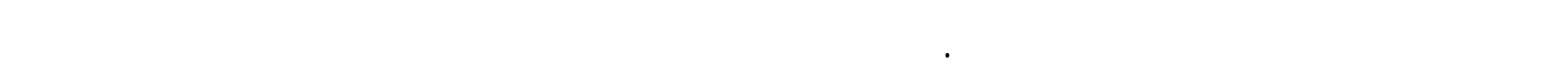

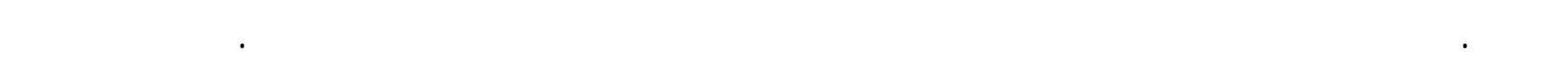

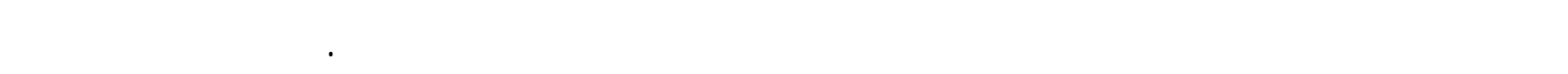

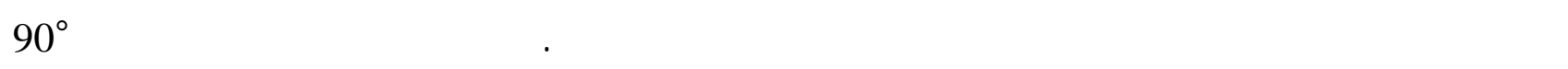
سليزية في تموز وْ70سليزية في تشرين الثاني. وبالظار إلىطبيعة الكربون غير السلمة ورخص كالفته، فإنه يوفر بنيلا جيدا يمكن اعتماده في عمل سخانت الماء الحرارية المحلية الصنع. 


\section{INTRODUCTION}

Solar energy is a natural renewable source which originates in the sun. The use of solar energy has a promising potential. Solar energy is converted into thermal energy by using solar collectors. Batch-type homemade solar water heaters are among the most costeffective solar devices.

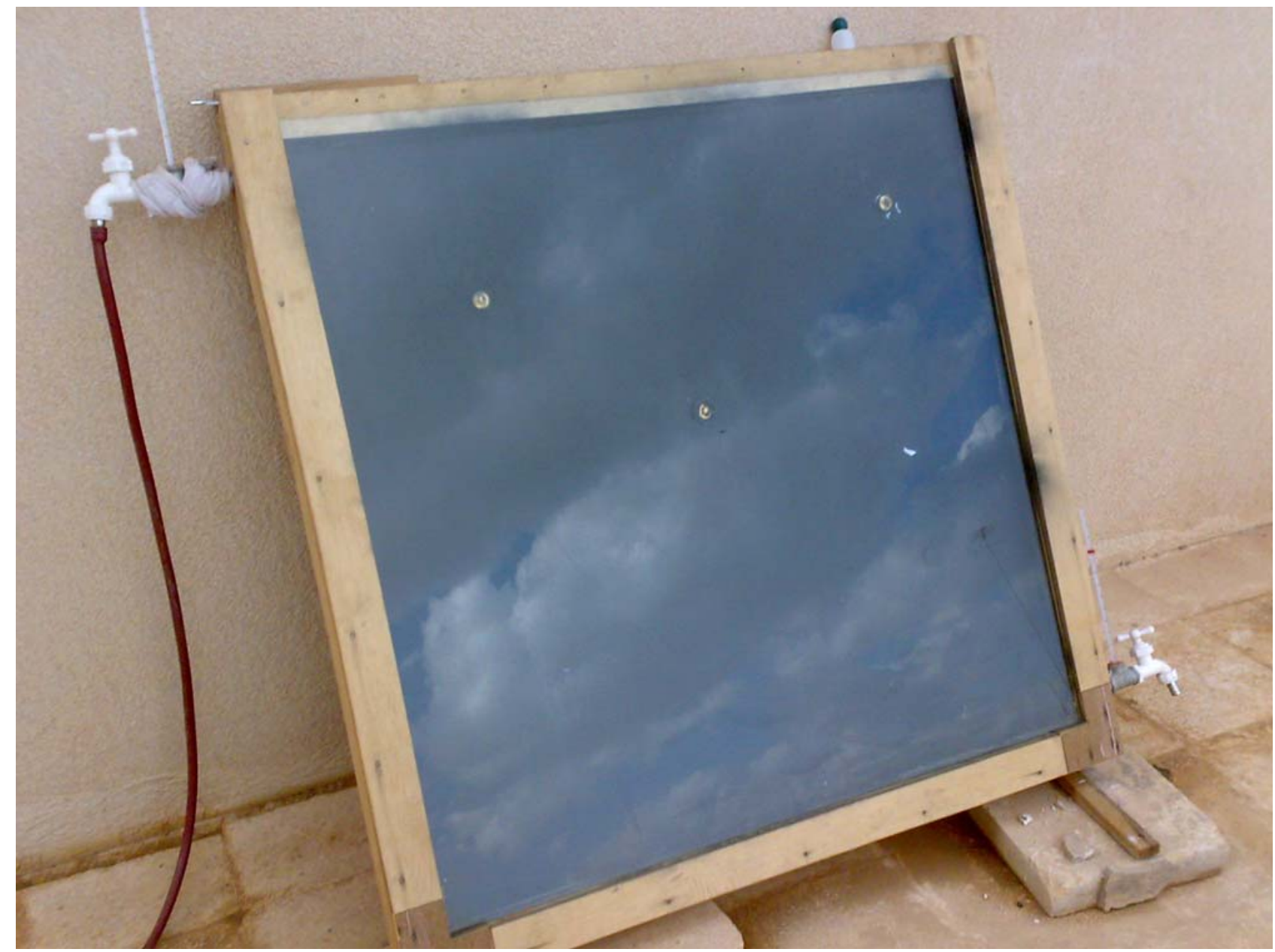

Fig. 1: A homemade solar water heater device.

Many workers have investigated different ways for exploiting solar energy. A domestic solar water heater uses the sun to heat water for household uses. A rough black surface absorbs all wave lengths in the visible spectrum. Conversely, the transparent glass cover allows nearly all radiation to pass through it without little reflection or absorption, and without deflecting it from its parallel travel lines.

Different types of absorbing materials are in use. Solar energy is easily obtained by a black surface coated with a thin layer of black paint. An effective utilization of solar energy involves maximum absorption of the incident solar radiation and minimum emission of heat (Katzen et al., 2005). A solar absorbing surface is a key component of the solar water heater and its properties and quality control both heat gains and losses.

Silicon solar cells are very efficient components. However, the widespread use of these cells is largely limited to the developed areas because of the expensive production 
cost. Researchers have therefore been investigating ways to develop solar cells based on organic materials which are more flexible and cheaper to produce than silica solar panels (NPG Asia materials, 2009).

Mitrea et al. (2008) used oxides coatings in their solar collectors. They remarked that coatings on solar collectors must have high absorption coefficient but low emission coefficient. Also, the coating must be able to absorb over 90\% of the solar energy. Two kinds of absorption materials were tested: oxide coatings and alumina cement.

Another technique described by Katzen et al. (2005) involves the use of new film structures based on porous silica and nanosized carbon for selective absorbers. This absorbing material showed high rates of absorbance of solar energy and very limited emission of heat.

An unusual procedure to grow layers of conductive $\mathrm{Bi}_{2} \mathrm{~S}_{3}$ films on fluorine-doped tin oxide glass substrate at room temperature was investigated by Zhou et al. (2006). Electrical characterization of $\mathrm{Bi}_{2} \mathrm{~S}_{3}$ films was conducted using photocurrent spectroscopy. Results of measurements showed that efficiency of heat absorption increased with increasing thickness of $\mathrm{Bi}_{2} \mathrm{~S}_{3}$ films.

In his thesis research, Ali (1979) tested an absorbing layer. The layer was fabricated from smoke suspension (soot) in oils. This layer enhanced the absorption of solar radiation and diminished heat emission. Efficiency of collector increased by $20 \%$ for $0.5 \mathrm{~mm}$ layer with smoke suspension.

Generally, absorber materials are governed by their durability and the expected service life (Carisson, 2004). Durability, in this case, is the ability of a material to resist deterioration caused by external factors in the environment (e.g. temperature, humidity and atmospheric corrosion), which may influence the performance of the material under service condition (Carisson, 2004).

This study describes the preparation and testing of an absorbing material for a homemade solar water heater. Mixtures of several proportions of carbon (soot) and oil paint were applied to the absorber's surface. The performance of the solar water heater was observed using four different coatings.

\section{EXPERIMENTAL PROCEDURE}

A homemade passive solar water heater $(1 \mathrm{~m} \times 1 \mathrm{~m})$ was positioned facing South at an angle of $45^{\circ}$ for the purpose of this study. The surface was coated with a layer made up of a mixture of carbon (soot) and oil-based white paint. Four coatings with different carbon proportions were applied to the absorbing surface to monitor the performance of the system on four separate sunny days in July and November 2010 (Tables 1 and 2). Weight percentages of carbon in the coating layers were 20,30, 40 and 50. Coating thicknesses increased as carbon percentage increased. At the 50\% mark, the coating was almost $0.5 \mathrm{~mm}$ thick.

Water temperature was recorded during a 14 hour period starting at 06:00 a.m. for the month of July and for an 11 hour period for the month of November (Tables 1 and 2). For everyday during the experiment, the tank was first drained and then filled up with water provided from a nearby tank placed in the shade. Inlet as well as outlet water temperatures were recorded at one-hour interval. 


\section{RESULTS AND DISCUSSION}

Performance of the absorbing surface is determined by measuring its solar absorption and heat emission. The use of absorber material is governed by its cost durability and expected service life (Carisson, 2004). High quality absorber materials, such as silicon, are very efficient but are also very expensive.

The use of carbon (soot) which is cheap and non-toxic provided a good alternative for an absorbing material in this study. Absorption of solar radiation increased with the increase of carbon percentage in the coating layer (Tables 1 and 2). The highest water temperatures achieved were $90^{\circ} \mathrm{C}$ for the month of July and $70^{\circ} \mathrm{C}$ for the month of November with $50 \%$ carbon in the paint. All peak water temperatures were recorded during the 12:00-13:00 period. It is obvious that during that period (12:00-13:00), the angle of incidence of solar radiation was at its maximum as a result of increasing of solar altitude. In addition, for all test days, outlet water temperatures remained above $45^{\circ} \mathrm{C}$ the next morning in July. Whereas, those of November were below $30^{\circ} \mathrm{C}$.

It should be mentioned that in July 2010 recordings, the rise in outlet water temperatures during the period 8:00-9:00 was relatively low particularly for the 20 and $40 \%$ coating. This could possibly attributed to the angle of solar radiation at that period.

Table 1: Recordings of water temperatures for the four coatings (July, 2010).

\begin{tabular}{|c|c|c|c|c|c|c|c|c|}
\hline $\begin{array}{c}\begin{array}{c}\% \\
\text { of } \\
\text { carbon }\end{array} \\
\text { in paint }\end{array}$ & \multicolumn{2}{|c|}{20} & \multicolumn{2}{|c|}{30} & \multicolumn{2}{|c|}{40} & \multicolumn{2}{|c|}{50} \\
\hline $\begin{array}{l}\text { Date } \\
\mathrm{T}^{\circ} \mathrm{C}\end{array}$ & \multicolumn{2}{|c|}{$\begin{array}{c}\text { 09/07/2010 } \\
\mathrm{H}: 43^{\circ} \mathrm{C} ; \mathrm{L}: 31^{\circ} \mathrm{C}\end{array}$} & \multicolumn{2}{|c|}{$\begin{array}{c}12 / 07 / 2010 \\
\mathrm{H}: 45^{\circ} \mathrm{C} ; \mathrm{L}: 29^{\circ} \mathrm{C}\end{array}$} & \multicolumn{2}{|c|}{$\begin{array}{c}17 / 07 / 2010 \\
\mathrm{H}: 42^{\circ} \mathrm{C} ; \mathrm{L}: 30^{\circ} \mathrm{C}\end{array}$} & \multicolumn{2}{|c|}{$\begin{array}{c}19 / 07 / 2010 \\
\mathrm{H}: 43^{\circ} \mathrm{C} ; \mathrm{L}: 28^{\circ} \mathrm{C}\end{array}$} \\
\hline & Inlet & Outlet & Inlet & Outlet & Inlet & Outlet & Inlet & Outlet \\
\hline 06:00 & 28 & 28 & 30 & 30 & 28 & 28 & 29 & 29 \\
\hline 07:00 & 30 & 42 & 32 & 44 & 29 & 43 & 30 & 44 \\
\hline 08:00 & 30 & 50 & 34 & 60 & 30 & 62 & 31 & 65 \\
\hline 09:00 & 31 & 51 & 35 & 62 & 32 & 65 & 31 & 71 \\
\hline $10: 00$ & 31 & 60 & 35 & 70 & 31 & 72 & 31 & 77 \\
\hline $11: 00$ & 32 & 67.5 & 36 & 79 & 32 & 80 & 32 & 85 \\
\hline $12: 00$ & 33 & 72 & 36 & 84 & 33 & 87 & 33 & 89 \\
\hline $13: 00$ & 33 & 73 & 36 & 81 & 34 & 81.5 & 33 & 90 \\
\hline $14: 00$ & 33 & 71 & 37 & 76 & 34 & 78 & 33 & 85 \\
\hline $15: 00$ & 34 & 69 & 36 & 72 & 33 & 74 & 33 & 80 \\
\hline $16: 00$ & 34 & 66 & 36 & 69 & 32 & 72 & 34 & 76 \\
\hline $17: 00$ & 34 & 64 & 36 & 66 & 32 & 70 & 34 & 72 \\
\hline 18:00 & 34 & 61.5 & 36 & 63 & 32 & 67 & 34 & 70 \\
\hline 19:00 & 34 & 59 & 36 & 60 & 32 & 64 & 34 & 67 \\
\hline
\end{tabular}


Generally, water temperatures of the four coatings exhibit one distinct pattern. A rapid rise in water temperature followed by a slightly slower drop around noon (Figs. 2 and 3).

Thicknesses of coating layers increased with the increase of carbon proportion in the paint. Hence, solar absorption increased as the thickness of the layer increased. However, attempts to increase the amount of carbon in the paint beyond the $50 \%$ mark did not succeed as no homogeneous mixture could be obtained to provide a coating layer.

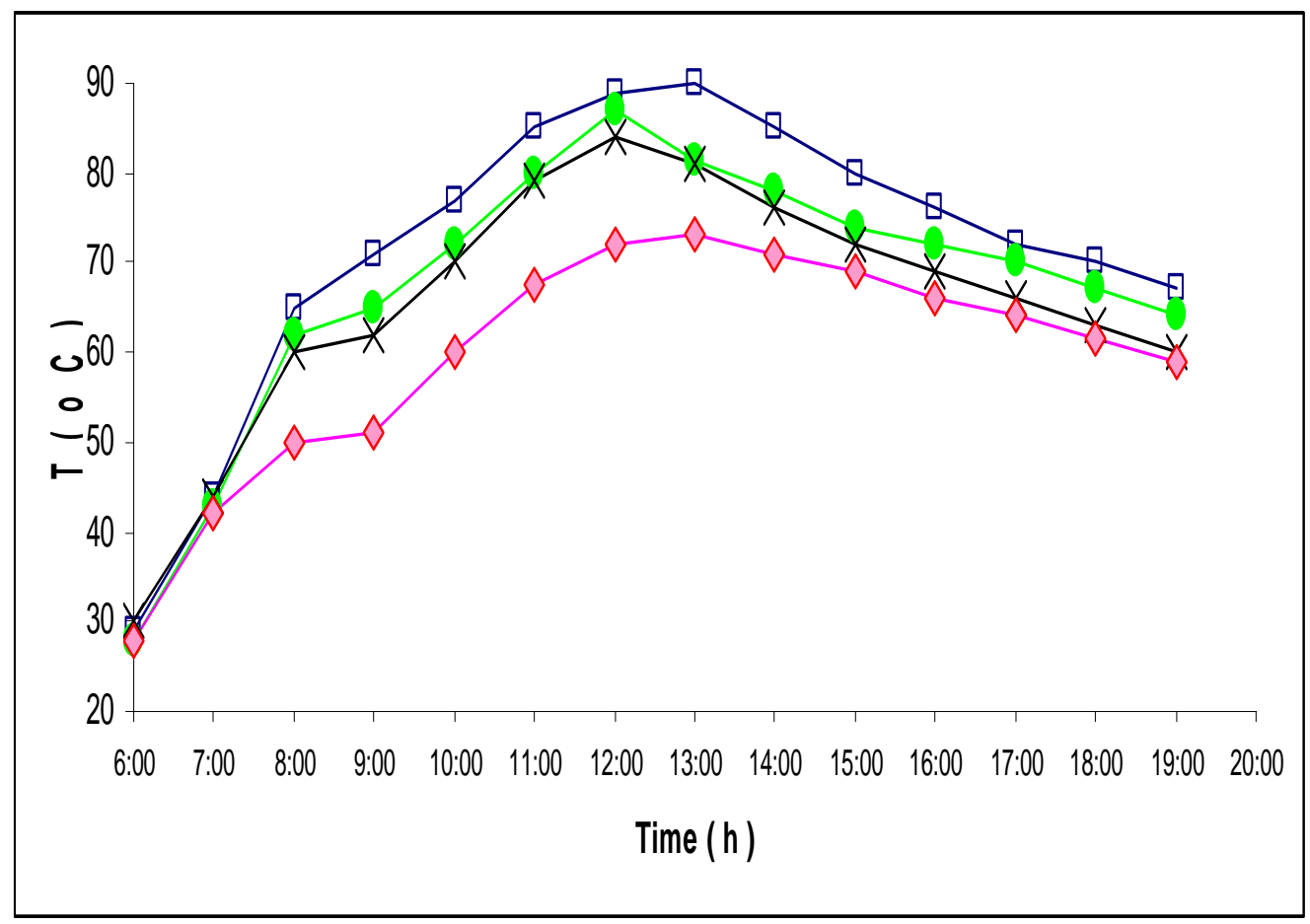

Fig. 2: Response of outlet water temperatures (July, 2010) to the percentage of carbon in the absorbing surface. $20 \%$ carbon (solid diamonds), $30 \%$ carbon (crosses), $40 \%$ carbon (solid circles) and $50 \%$ carbon (open squares). 
Table 2: Recordings of water temperatures for the four coatings (November, 2010).

\begin{tabular}{|c|c|c|c|c|c|c|c|c|}
\hline $\begin{array}{c}\% \\
\text { of } \\
\text { carbon } \\
\text { in paint }\end{array}$ & \multicolumn{2}{|c|}{20} & \multicolumn{2}{|c|}{30} & \multicolumn{2}{|c|}{40} & \multicolumn{2}{|c|}{50} \\
\hline $\begin{array}{l}\text { Date } \\
\mathbf{T}^{\circ} \mathrm{C} \\
\end{array}$ & \multicolumn{2}{|c|}{$\begin{array}{c}03 / 11 / 2010 \\
\mathrm{H}: 27^{\circ} \mathrm{C} ; \mathrm{L}: 8.5^{\circ} \mathrm{C}\end{array}$} & \multicolumn{2}{|c|}{$\begin{array}{c}06 / 11 / 2010 \\
\mathrm{H}: 27.5^{\circ} \mathrm{C} ; \mathrm{L}: 5^{\circ} \mathrm{C} \\
\end{array}$} & \multicolumn{2}{|c|}{$\begin{array}{c}11 / 11 / 2010 \\
\mathrm{H}: 28^{\circ} \mathrm{C} ; \mathrm{L}: 9.4^{\circ} \mathrm{C}\end{array}$} & \multicolumn{2}{|c|}{$\begin{array}{c}14 / 11 / 2010 \\
\mathrm{H}: 28.5^{\circ} \mathrm{C} ; \mathrm{L}: 7.5^{\circ} \mathrm{C} \\
\end{array}$} \\
\hline & Inlet & Outlet & Inlet & Outlet & Inlet & Outlet & Inlet & Outlet \\
\hline $07: 00$ & 10 & 10 & 8 & 8 & 11 & 11 & 9 & 9 \\
\hline 08:00 & 10 & 14 & 9 & 15 & 11 & 17 & 9 & 16 \\
\hline 09:00 & 11 & 19 & 10 & 21 & 11 & 24 & 9 & 26 \\
\hline $10: 00$ & 12 & 26 & 11 & 32 & 11 & 35 & 10 & 38 \\
\hline $11: 00$ & 12 & 32 & 11 & 41 & 12 & 45 & 10 & 49 \\
\hline $12: 00$ & 12 & 40 & 13 & 47 & 13 & 55 & 11 & 60 \\
\hline $13: 00$ & 13 & 45 & 13 & 54 & 13 & 62 & 11 & 70 \\
\hline $14: 00$ & 13 & 40 & 13 & 49 & 13 & 55 & 12 & 62 \\
\hline $15: 00$ & 14 & 36 & 14 & 40 & 14 & 43 & 13 & 53 \\
\hline $16: 00$ & 14 & 30 & 14 & 32 & 14 & 34 & 13 & 41 \\
\hline $17: 00$ & 14 & 24 & 14 & 25 & 14 & 28 & 13 & 32 \\
\hline
\end{tabular}

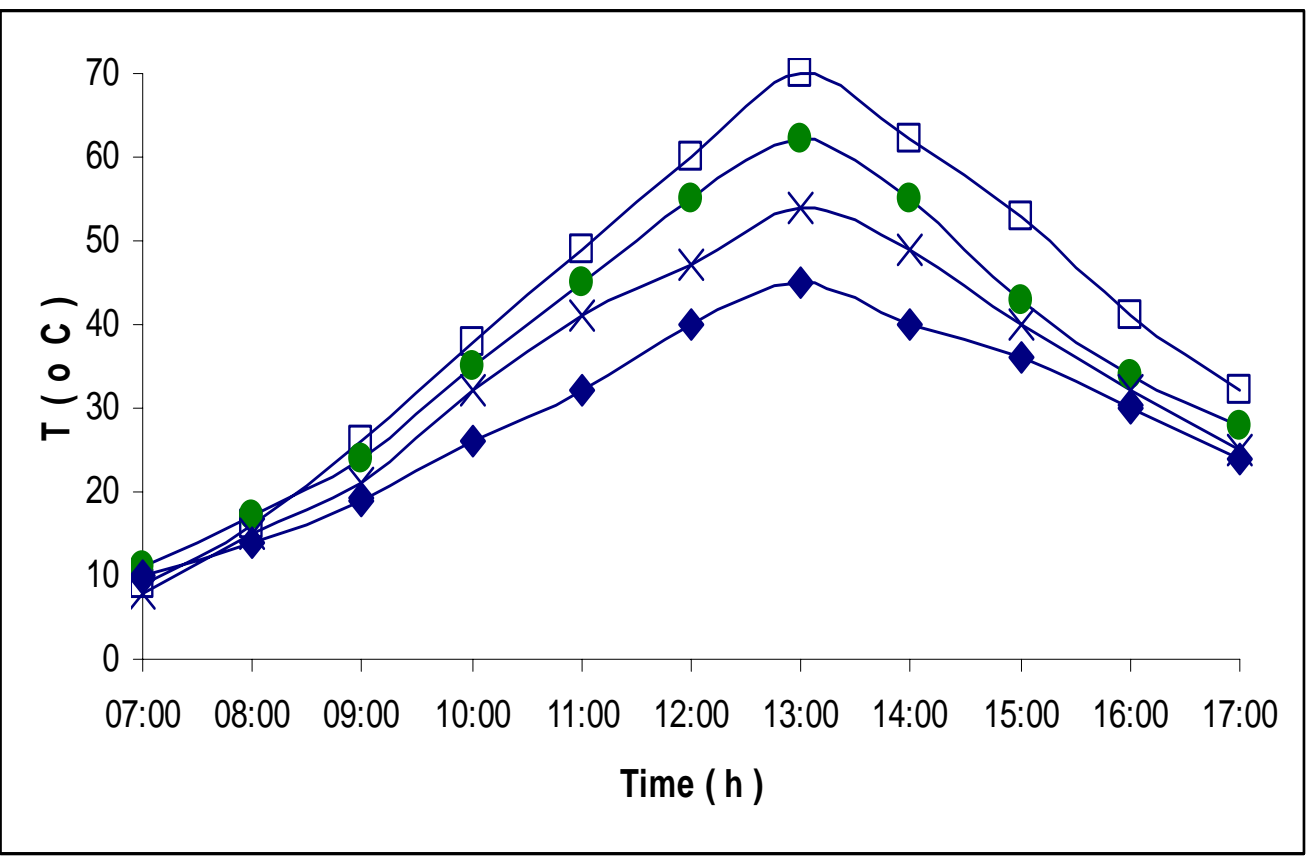

Fig. 3: Response of outlet water temperatures (November, 2010) to the percentage of carbon in the absorbing surface. $20 \%$ carbon (solid diamonds), $30 \%$ carbon (crosses), $40 \%$ carbon (solid circles) and $50 \%$ carbon (open squares). 


\section{CONCLUSIONS}

Carbon in the form of smoke suspension (soot) added to oil-based white paint provided a low cost non-toxic material in the fabrication of a homemade solar water heater. Four different coating layers with carbon percentages 20, 30, 40 and 50 were tested for four days.

Outlet water temperatures showed marked increases with the increase of carbon proportion in the coating layer. The higher the carbon percentage, the thicker the coating layer and therefore the higher the solar absorption. The maximum water temperatures obtained were $90^{\circ} \mathrm{C}$ in July and $70^{\circ} \mathrm{C}$ in November when both coating layers had $50 \%$ carbon in the mixture. Next morning temperature was well above $45^{\circ} \mathrm{C}$ during the experiment, during the month of July.

\section{ACKNOWLEDGMENTS}

The author wishes to thank Dr. A.A. Azooz for suggesting this research and for his kind support.

\section{REFERENCES}

Ali, D.M.J., (1979). The design and performance of solar energy collector made of absorbing layer backed by a reflector. Unpub. M.Sc. thesis, Physics Department, Mosul University, 86p.

Carisson, B., (2004). Recommended qualification test procedure for solar absorber surface durability. IEA Solar Heating and Cooling prog., 28.

Katzen, D.; Levy, E.; Mastai, Y., (2005). Thin films of silica-carbon nanocomposites for selective solar absorber. Applied Surface Science, (248), 514-517.

Mitrea, S.A.; Hodorogea, S.M.; Duta, A.; Isar, L.; Durghel, E.; Voinea, (2008). Some aspects regarding I.R. absorbing materials based on thin alumina films for solarthermal energy conversion, using X-Ray Diffraction technique. World Acad. Sci., Engin. and Techn., (47), 360-363.

NPG Asia Materials, (2009). Organic Solar Cells. Absorbing Solutions, 1-2.

Zhou, L.; Govender, K.; Boyle, D.S.; Dale, P.I.; Peter, L.M.; O'brien, P., (2006). Single step solution deposition of multilayer solar absorber films at ambient temperature. $J$. Materials Chem., (16), 3174-3176. 